DOI: $10.19195 / 0524-4544.325 .2$

\title{
DOBROMIŁA NOWICKA
}

ORCID: 0000-0002-1480-7281

Uniwersytet Wrocławski

dobromila.nowicka@uwr.edu.pl

\section{Wyłączenie od zeznawania i prawo odmowy zeznań w rzymskim procesie karnym}

Zeznania świadków były niewątpliwie najważniejszym środkiem dowodowym w rzymskich postępowaniach w sprawach karnych. Im także - poza zagadnieniami związanymi z przesłuchiwaniem niewolników — juryści poświęcali najwięcej uwagi ${ }^{1}$. Zarówno z uwagi na najobszerniejszą bazę źródłową, jak i znaczenie zeznań świadków jako podstawowego środka dowodowego w procedurach przed quaestiones perpetuae ${ }^{2}$ tematyka ta nieprzerwanie cieszy się zainteresowaniem doktryny romanistycznej ${ }^{3}$. Poza samą procedurą i taktyką przesłuchiwania świadków oraz kwestią ich wiarygodności najistotniejszym zagadnieniem wydaje się w tym zakresie możliwość uchylenia się od złożenia zeznań. Co do zasady bowiem świadek oskarżenia wezwany do pełnienia tej funkcji w procesie karnym zmuszony był do złożenia zeznań, nawet gdy był niechętny temu obowiązkowi ${ }^{4}$. Istniały jednak kategorie osób, które w ogóle nie mogły występować w roli

1 Zob. jednak G. Pugliese, La prova nel processo romano classico, „Jus” 11, 1960, s. 386; W. Rozwadowski, Ocena zeznań świadków w procesie rzymskim epoki republikańskiej, „Czasopismo Prawno-Historyczne" 13, 1961, s. 11.

2 Na temat quaestiones perpetuae zob. zwłaszcza W. Kunkel, Quaestio, [w:] Kleine Schriften, Weimar 1974, s. 56-102.

${ }^{3}$ Gdy chodzi o przegląd starszej doktryny w zakresie tej tematyki, zob. np. S. Messina, La testimonianza nel processo penale romano, „Rivista penale” 73, 1911, s. 278-299; M. Kaser, s.v. testimonium, [w:] RE, t. 5 A I 1934, s. 1021-1061.

${ }^{4}$ Zob. np. A.W. Zumpt, Das Criminalrecht der Römischen Republik, Berlin 1869, s. 273-276; B. Cohen, Testimonial Compulsion in Jewish, Roman, and Moslem Law, „IVRA” 9/1, 1958, s. 11, przyp. 42; A.D. Manfredini, La testimonianza del liberto contro il patrono nel processo criminale di età classica, [w:] Studi in onore di Arnaldo Biscardi, t. 3, Milano 1982, s. 223-224. Jako że wspomniany przymus ograniczony był do świadków powoływanych przez stronę oskarżycielską, 
świadków na niekorzyść oskarżonego lub nie mogły pełnić tej funkcji w konkretnej sprawie, a także grupa tych, którym przysługiwało prawo uchylenia się od konieczności zeznawania. W przypadku braku zdolności zeznawania przeciw oskarżonemu podstawą dyskwalifikacji był aprioryczny brak zaufania do dostarczanych przez nich świadectw bądź to z uwagi na sposób życia, bądź też relacje $\mathrm{z}$ oskarżonym ${ }^{5}$, a także zbyt młody wiek ${ }^{6}$. Na gruncie lex Iulia de vi świadczy o tym przekaz Callistratusa (libro quarto de cognitionibus) ${ }^{7}$ :

\section{22.5.3.5:}

Lege Iulia de vi cavetur, ne hac lege in reum testimonium dicere liceret, qui se ab eo parenteve eius liberaverit, quive impuberes erunt, quique iudicio publico damnatus erit qui eorum in integrum restitutus non erit, quive in vinculis custodiave publica erit, quive ad bestias ut depugnaret se locaverit, quaeve palam quaestum faciet feceritve, quive ob testimonium dicendum vel non dicendum pecuniam accepisse iudicatus vel convictus erit. Nam quidam propter reverentiam personarum, quidam propter lubricum consilii sui, alii vero propter notam et infamiam vitae suae admittendi non sunt ad testimonii fidem.

Tej samej kwestii dotyczy fragment zaczerpnięty z libro VIIII de officio proconsulis Ulpianusa, a przekazany w Collatio legum Mosaicarum et Romanarum 9.2.2:

Capite octogesimo octavo in haec verba his hominibus: "hac lege in reum testimonium dicere ne liceto, qui se ab eo parenteve eius libertove cuius eorum libertive libertave liberaverit, quive inpubes erit, quive iudicio publico damnatus est, qui eorum in integrum restitutus non est, quive in vinculis custodiaque publica erit, quive depugnandi causa auctoratus erit, quive ad bestias depugnare se locavit locaverit, praeterquam qui iaculandi causa ad urbem missus est erit, palamve corpore quaestum faciet feceritve, quive ob testimonium dicendum pecuniam accepisse iudicatus erit". Nec volens quis eorum hac lege in reum testimonium dicit.

Podkreślenia wymaga, że zestawienie obu przekazów, to jest cytowanego wyżej tekstu Callistratusa oraz wskazanego tu przekazu pochodzącego od Ulpia-

problematyka możliwości uchylenia się od złożenia zeznań w związku z bliską relacją z oskarżonym odnosiła się jedynie do świadectw dla niego niekorzystnych.

5 Dyskwalifikacje mające wydźwięk generalny, a które zostały pominięte w dalszych rozważaniach, odnoszą się do wyłączeń sędziów orzekających w sprawie i obrońców (D. 22.5.25), a także osób, które oskarżyciel przyprowadził ze swego domu (D. 22.5.24). Zob. A.W. Zumpt, op. cit., s. 271-272. Por. też W. Rozwadowski, Ocena zeznań świadków w procesie rzymskim epoki Pryncypatu, „Czasopismo Prawno-Historyczne” 16, 1964, s. 169-172. Ponadto gdy chodzi o świadków oskarżenia, dodatkową przesłanką wyłączającą takie zeznanie było uprzednie występowanie w tej roli wobec tego samego oskarżonego (D. 22.5.23). Zob. L. Fanizza, Giuristi, crimini, leggi nell'età degli Antonini, Napoli 1982, s. 35-37; U. Vincenti, »Duo genera sunt testium«. Contributo allo studio dela prova testimoniale nel processo romano, Padova 1989, s. 74; D.V. Piacente, Casi di incapacità a testimoniare tra legislazione e giurisprudenza, „Index” 42, 2014, s. 427-428. Por. jednak w tym zakresie C. 4.20 .13 z komentarzem W. Rozwadowskiego, Wartość dowodowa świadków w rzymskim procesie poklasycznym, „Czasopismo Prawno-Historyczne” 21, 1969, s. 9-10, 15-16.

${ }^{6}$ Zob. też A. Nogrady, Römisches Strafrecht nach Ulpian: Buch 7 bis 9 De officio proconsulis, Berlin 2006, s. 233-234.

7 Zob. też A.D. Manfredini, op. cit., s. 226-228; U. Vincenti, op. cit., s. 111-112; D.V. Piacente, op. cit., s. 418-422.

Prawo 325, 2018

(C) for this edition by CNS 
nusa, prowadzi do wniosku, że żaden z jurystów nie wymienił wszystkich podstaw dyskwalifikacji do bycia świadkiem oskarżenia na gruncie lex Iulia de $v i^{8}$, a teksty wzajemnie się uzupełniają. W obu przypadkach można dostrzec wyraźny i niepodlegający wątpliwościom trzon w postaci wyłączenia impuberes $^{9}$, wyzwoleńców strony, wynajmujących się do walk z dzikimi zwierzętami, osób skazanych w iudicium publicum, które nie uzyskały restitutio in integrum ${ }^{10}$, a także skazanych za składanie lub odmowę składania zeznań w zamian za gratyfikację pieniężną ${ }^{11}$. Z przesłanek niewymienionych u Ulpianusa Callistratus wspomina o byłych i czynnych prostytutkach ${ }^{12}$. Z kolei Ulpianus wskazuje gladiatorów i występujących publicznie dla osiągnięcia korzyści majątkowej. Dodatkowo jurysta zaznacza, że mimo walki z dzikimi bestiami nie są zdyskwalifikowani od zeznawania ci, którzy zostali lub mają być wysłani w celu wykonania rzutów oszczepem. Wydaje się zatem, że chociaż juryści różnią się w tym punkcie co do wskazanych zawodów, które wyłączają od możliwości złożenia zeznań na niekorzyść oskarżonego, chodzi o tę samą podstawę - są to zawody uznane za hańbiące, więc zeznania nimi się parających nie są wiarygodne. Stąd też wymienione

8 Ograniczenie regulacji tylko do spraw dotyczących przestępstwa vis, bez możliwości zastosowania w tym przypadku interpretacji rozszerzającej, nie budzi wątpliwości. Zob. też A.W. Zumpt, op. cit., s. 263-266.

9 Zaznaczenia w tym kontekście wymaga generalny wydźwięk przekazu Venuleiusa (libro secundo de iudiciis publicis), zgodnie z którym oskarżyciel nie powinien wzywać na świadka osoby, która nie ukończyła dwudziestu lat. Zob. D. 22.5.20. Na tej podstawie można uznać, że jurysta nawiązuje tu do reżimu ukształtowanego przez lex Iulia iudiciorum publicorum (tak np. V. Giuffre, La repressione criminale nell'esperienza romana, Napoli 1997, s. 152-153; L. Fanizza, op. cit., s. 35, 37-39; D.V. Piacente, op. cit., s. 428). Należałoby wówczas przyjąć, że lex Iulia de vi publica przewidywał w tej kwestii regulację bardziej liberalną niż ustawa „ogólna”. Por. także pogląd U. Vincentiego, który uważa, że mogło chodzić o regulacje wprowadzone przez senat lub cesarza — zob. U. Vincenti, op. cit., s. 61-63. Zob. też przyp. 11.

10 Za słuszny należy uznać pogląd, zgodnie z którym nie chodziło o skazanie w każdym iudicium publicum, lecz o przypadki, gdy ustawa szczególna wyraźnie przewidywała taki skutek w danym przestępstwie. Zob. W. Rozwadowski, Ocena zeznań świadków w procesie rzymskim epoki Pryncypatu..., s. 156-158. Por. też D. Simon, Untersuchungen zum justinianischen Zivilprozess, München 1969, s. 237-239. Zob. jednak przyp. następny.

11 Brakuje natomiast wyłączenia z powodu skazania za calumnia zarówno przez samą lex Remmia, jak i wiele ustaw ustanawiających poszczególne quaestiones, w tym de vi, de repetundis oraz de peculatu, a także, jak można zasadnie zakładać na podstawie przekazu Papinianusa (libro primo de adulteriis), na gruncie lex Iulia iudiciorum publicorum. Zob. D. 22.5.13 z komentarzem U. Vincentiego, op. cit., s. 55-56. Por. jednak pogląd Venuleiusa (libro secundo de iudiciis publicis) o tym, że po stronie oskarżycielskiej nie powinien być powołany nawet świadek, który występował w iudicium publicum jako oskarżony (to jest także, jak się wydaje, w braku skazania). Zob. D. 22.5.20. Podkreślenia wymaga, że w tym zakresie jest to odosobnione świadectwo jurysty. Por. też L. Fanizza, op. cit., s. 40, która podkreśla, że z kolei wzmianki o dyskwalifikacji skazanego/skazanej pojawiają się wprost w kontekście crimen repetundarum (np. D. 22.5.15 pr.) oraz adulterium (D. 22.5.18). O pochodzeniu uregulowania, o którym wspomina Venuleius z lex Iulia iudiciorum publicorum, także D.V. Piacente, op. cit., s. 429.

12 Por. w tym zakresie A.W. Zumpt, op. cit., s. 266. 
w tym kontekście kategorie osób należy uznać za wskazane przez jurystów przykładowo jako mające zobrazować przesłankę dyskwalifikacji z powodu wykonywania (również w przeszłości) zawodów infamujących. Świadectwa te różnią się także pod względem określenia grona osób zdyskwalifikowanych od zeznawania w związku z wyzwoleniem. U Callistratusa zeznawać przeciw oskarżonemu nie może wyzwoleniec jego samego lub osoba wyzwolona przez jego rodziców (lub szerzej — ascendentów), podczas gdy u Ulpianusa krąg ten jest szerszy, wyłączając od wystąpienia jako świadka na niekorzyść oskarżonego również wyzwoleńców ich wyzwoleńców, a także wyzwoleńców tych ostatnich. Oczywiście zasada ma także zastosowanie do wyzwolenic. Wydaje się zatem, że Ulpianus dokonał tutaj interpretacji rozszerzającej, dyskwalifikując obciążające zeznania wszystkich, których wolność miała źródło w wyzwoleniach dokonywanych przez oskarżonego lub jego wstępnych.

Odrębną kategorię stanowili ci, którzy mogli zeznawać, lecz nie można było ich do tego zmusić wbrew ich woli. Także w tym przypadku możemy wyróżnić dwie podkategorie osób, odpowiadające dwóm różnym podstawom prawa do odmowy zeznań. Pierwsza podstawa jest niezależna od osoby oskarżonego, zatem obowiązuje bezwzględnie, dotycząc możliwości uchylenia się od zeznań z uwagi na zaawansowany wiek, inwalidztwo lub służbę wojskową bądź państwową. Potwierdza to pogląd Scaevoli (libro quarto regularum):

D. 22.5.8: „Inviti testimonium dicere non coguntur senes valetudinarii vel milites vel qui cum magistratu rei publicae causa absunt vel quibus venire non licet".

Zarówno sama kategoria, jak i przyczyna zwolnienia z obowiązku zeznawania wbrew woli nie budzą w tym przypadku większych wątpliwości, jako że wynikają z szacunku wobec wieku, stanu zdrowia lub pełnionej funkcji.

Druga grupa osób, którym przysługuje prawo odmowy zeznań obciążających w związku z relacją z oskarżonym, budzi już więcej kontrowersji. Wynikają one $\mathrm{z}$ fragmentarycznych przekazów co do regulowania tej kwestii w różnych, choć tylko niektórych, ustawach, co wprowadza wątpliwości co do rodzaju uprawnień kategorii osób najbliższych oskarżonemu. Istnieją bowiem rozbieżności co do traktowania zeznań patronów i wyzwoleńców oraz rodziców i dzieci na gruncie różnych uregulowań, podobnie jak niejasna jest sytuacja uprawnień współmałżonka w kwestii odmowy zeznań. Co do pierwszych dwóch kategorii osób zagadnieniem wątpliwym jest istnienie prawa do odmowy zeznań lub całkowitego zakazu zeznawania $\mathrm{w}$ takich przypadkach ${ }^{13}$. Z kolei małżeństwo nie jest wprost wymieniane jako odrębna podstawa ani jednego, ani drugiego.

Bazą rozważań w kwestii prawa odmowy zeznań w rzymskich postępowaniach karnych są dwa przekazy źródłowe. Pierwszy odnosi się do regulacji ju-

13 W odniesieniu do prawa klasycznego zob. zwłaszcza A.D. Manfredini, op. cit., s. 223-243, z podaną tam literaturą. 
lijskiej ustawy o postępowaniach publicznych ${ }^{14}$, której zasady obowiązywały zawsze, gdy ustawa szczególna nie przewidywała odstępstw. Zgodnie z niżej cytowanym przekazem Paulusa nie było możliwe zmuszenie do świadczenia przeciw teściowi, zięciowi, ojczymowi, pasierbowi, kuzynowi lub kuzynce oraz ich dzieciom oraz wszystkim bliższych stopniem od osób wymienionych.

D. 22.5.4 (Paulus libro secundo ad legem Iuliam et Papiam):

Lege Iulia iudiciorum publicorum cavetur, ne invito denuntietur, ut testimonium litis dicat adversus socerum generum, vitricum privignum, sobrinum sobrinam, sobrino sobrina natum, eosve qui priore gradu sint, item ne liberto ipsius, liberorum eius, parentium, viri uxoris, item patroni patronae: et ut ne patroni patronae adversus libertos neque liberti adversus patronum cogantur testimonium dicere.

Analogicznie traktowano patrona i patronkę, których nie można było zmusić do zeznań przeciw ich wyzwoleńcowi, tak jak wyzwoleńca przeciw jego patronom, przy czym nie chodziło jedynie o relację z wyzwoleńcem własnym, lecz także osobami wyzwolonymi przez najbliższych — dzieci, rodziców (lub szerzej - ascendentów) czy współmałżonka.

Co do pierwszej grupy podmiotów, podstawą uprawnienia do odmowy zeznań jest pokrewieństwo w stopniach wymienionych w tekście lub bliższe, a także dwie relacje wynikające $\mathrm{z}$ powinowactwa: między ojczymem a pasierbem oraz zięciem a teściem. Dodatkowo w związku z przekazem Gaiusa ${ }^{15}$ należy uznać, że reguła $\mathrm{w}$ odniesieniu do ostatnich $\mathrm{z}$ wymienionych kategorii osób ma zastosowanie już na etapie narzeczeństwa, zatem prawo odmowy zeznań przysługiwało także narzeczonemu córki oraz ojcu narzeczonej. Analogiczne uprawnienie, jak można zakładać, przysługiwało $\mathrm{w}$ relacji między osobami płci żeńskiej. Wobec braku stopni powinowactwa w prawie rzymskim ${ }^{16}$ wskazanie na ,bliższych stopniem" można odnosić jedynie do wymienionych w tekście relacji opartych na pokrewieństwie.

W tym też zakresie należy sformułować pierwsze wątpliwości. Dotyczą one uprawnień do odmowy zeznań w dwóch relacjach: rodzice-dzieci oraz mąż-

${ }^{14} \mathrm{Na}$ temat ustawy zob. zwłaszcza T. Gatti, I limiti delle leges iudiciorum publicorum, „Archivio Giuridico” 113, 1935, s. 59-70; idem, I limiti delle leges iudiciorum publicorum, „Archivio Giuridico" 115, 1936, s. 44-59; R.A. Bauman, The 'leges iudiciorum publicorum' and Their Interpretation in the Republic, Principate and Later Empire, [w:] Aufstieg und Niedergang der römischen Welt, t. 2.13, Berlin 1980, s. 103-233; F.P. Casavola, Gli ordinamenti giudiziari nella Roma imperiale. "Princeps « e procedure dalle leggi Giulie ad Adriano, „Index” 26, 1998, s. 89-98; J. Giltaij, The problem of the content of the Lex Iulia iudiciorum publicorum, „Tijdschrift voor Rechtsgeschiedenis" 81,2013 , s. 507-525.

15 Zob. D. 22.5.5 (Gaius libro quarto ad legem Iuliam et Papiam): „In legibus, quibus excipitur, ne gener aut socer invitus testimonium dicere cogeretur, generi appellatione sponsum quoque filiae contineri placet: item soceri sponsae patrem".

16 Zob. D. 38.10.4.5 (Modestinus libro 12 pandectarum): „Gradus autem adfinitati nulli sunt”. 
żona ${ }^{17}$. Co do pierwszej kwestii, zgodnie z przekazem Paulusa należałoby uznać, że dopuszczalne jest przyjęcie zeznań na niekorzyść formułowanych przez ojca przeciw synowi i odwrotnie ${ }^{18}$. Jednak zgodnie z przekazem Paulusa (libro primo ad Sabinum) osoby te nie są wobec siebie odpowiednimi świadkami ${ }^{19}$ :

D. 22.5.9: „Testis idoneus pater filio aut filius patri non est”.

Trudności sprawia oczywiście interpretacja „niewłaściwości” bycia świadkiem w sprawie własnego ojca lub syna, jako że stwierdzenie to można rozumieć zarówno jako trwałą, bezwzględną dyskwalifikację, jak i sformułowanie pozwalające na odmowę zeznań bądź nawet jedynie ocenę jurysty, zgodnie z którą sytuacja zeznawania dzieci przeciw rodzicom lub odwrotnie, jakkolwiek jest formalnie dopuszczalna, jest niewłaściwa moralnie. W tym kontekście warto zatem przytoczyć bardzo podobne sformułowanie w przypadku zeznawania we własnej sprawie, a prezentowane przez Pomponiusa (libro primo ad Sabinum), w Digestach bezpośrednio sąsiadujące $\mathrm{z}$ analizowanym tekstem:

D. 22.5.10: „Nullus idoneus testis in re sua intellegitur”.

Jako że dyskwalifikujący wydźwięk tego stwierdzenia nie budzi wątpliwości ${ }^{20}$, per analogiam należałoby uznać, że także w przypadku relacji rodzice-dzieci nie chodzi o uprawnienie do odmowy zeznań, lecz wykluczenie ich składania. Powszechnie jednak przyjmuje się, że chodzi w tym przypadku nie o zeznania na niekorzyść, lecz te korzystne dla oskarżonego ${ }^{21}$. Późniejsze świadectwo zaczerpnięte z Pauli Sententiae wskazuje jednak, że relacja ta całkowicie wykluczała złożenie zeznań wzajemnie obciążających w relacji dzieci-rodzice:

Pauli Sententiae 5.15.3 (= Collatio legum Mosaicarum et Romanarum 9.3.3):

Adversus se invicem parentes et liberi itemque [patroni et] liberti nec volentes ad testimonium admittendi sunt, quia rei verae testimonium necessitudo personarum plerumque corrumpit.

Podobnie zagadnienie to postrzegali cesarze Diocletianus i Maximianus, którzy w konstytucji z 294 roku uznali, że nie można dopuścić wzajemnych zeznań na niekorzyść dzieci i rodziców, nawet jeśli dobrowolnie chcą je złożyć.

C. 4.20.6 (=B. 21.1.30): „Parentes et liberii invicem adversus se nec volentes ad testimonium admittendi sunt".

Należy zatem uznać, że relacja między rodzicami a dziećmi w prawie poklasycznym dyskwalifikowała te podmioty od wzajemnych zeznań na niekorzyść. Dla okresu klasycznego należy przyjąć jedynie istnienie prawa odmowy zeznań

17 Wcześniejszy brak ograniczonej tego rodzaju wydaje się wynikać ze zwyczajowego przyjęcia niezeznawania przeciw sobie tych kategorii osób. Zob. A.W. Zumpt, op. cit., s. 267-268.

18 Na gruncie D. 50.16.201 regulację tę należy rozumieć jako odnoszącą się do córek, a także wnuków oraz dziadków. Tak też W. Rozwadowski, Ocena zeznań świadków w procesie rzymskim epoki Pryncypatu..., s. 153-154.

19 Por. też D. Simon, op. cit., s. 243-247; U. Vincenti, op. cit., s. 112-113.

20 Por. także C. 4.20.9.

21 Zob. np. A.D. Manfredini, op. cit., s. 234. 
w takich sytuacjach, nie wykluczając jednak funkcjonowania szczególnych uregulowań w odniesieniu do poszczególnych przestępstw.

Drugą zaznaczoną wyżej kwestią wątpliwą na gruncie uregulowań lex Iulia iudiciorum publicorum jest brak wskazania małżonka jako osoby uprawnionej do odmowy składania zeznań, co stanowi rozwiązanie dość zaskakujące. Co ciekawe źródło wyraźnie odwołuje się do więzów pokrewieństwa i powinowactwa, nie zaś podległości zwierzchnictwu familijnemu, skutkując brakiem możliwości włączenia do katalogu osób uprawnionych do odmowy składania zeznań nie tylko żony niepodlegającej zwierzchnictwu męża, lecz także mu podlegającej. Przy szczegółowym określeniu relacji opartych na powinowactwie i wobec braku w prawie rzymskim stopni powinowactwa, których przyjęcie - w związku z odnoszeniem regulacji do wszystkich bliższym stopniem - mogłoby na podstawie niektórych poglądów pozwolić na włączenie małżonków do grona mogących odmówić zeznań, należy uznać, że małżeństwo nie stanowiło przesłanki uprawniającej do odstąpienia od zeznawania przeciw mężowi czy żonie. Kwestia ta została zatem pozostawiona do ewentualnej regulacji w odniesieniu do poszczególnych przestępstw.

Do takiego szczególnego unormowania w zakresie przekazów odnoszących się do prawa odmowy zeznań w rzymskim postępowaniu karnym należy świadectwo Ulpianusa dotyczące julijskiej ustawy o przemocy publicznej i prywatnej i to nie wcielone do kodyfikacji justyniańskiej, lecz przytoczone w Collatio.

\section{Collatio legum Mosaicarum et Romanarum 9.2.3:}

inviti in reum testimonium ne dicunto qui sobrinus est ei reo propritoreve cognatione coniunctus, quiue soccer gener vitricus privignusve eius erit [...].

W przypadku tym jednak katalog osób uprawnionych do odmowy zeznań na niekorzyść oskarżonego, z uwagi na więzy pokrewieństwa i powinowactwa, nie różni się od tego, który obowiązywał w lex Iulia iudiciorum publicorum, choć wyraźnie nie jest wyczerpujący. Także zatem w razie przestępstwa vis nie ma mowy o możliwości uchylenia się od złożenia zeznań obciążających małżonka/ małżonkę.

Drugą grupą podmiotów uprawnioną do odmowy zeznań na gruncie analizowanego fragmentu odnoszącego się do julijskiej ustawy o postępowaniu w sprawach publicznych są osoby związane z sobą poprzez fakt wyzwolenia - patroni (patronki) oraz ich wyzwoleńcy (wyzwolenice) ${ }^{22}$, przy czym uprawnienie to rozciągało się po stronie wyzwoleńców na prawo uchylenia się od zeznań także osób wyzwolonych przez dzieci, rodziców (lub szerzej — ascendentów) i współmałżonka oskarżonego. Wynika z tego, że na gruncie julijskiej ,ustawy ogólnej” o postępowaniach publicznych nie istniał zatem bezwzględny zakaz zeznań w relacji patron-wyzwoleniec.

Przeciwny wniosek można wysnuć z cytowanego wyżej przekazu zaczerpniętego z Pauli Sententiae, jako że jurysta, oprócz relacji dzieci-rodzice, odnosi

22 Por. też D. Simon, op. cit., s. 247-248; A.D. Manfredini, op. cit., s. 229-236. 
się w nim także do tej łączącej wyzwoleńców i patronów, którzy również pozbawieni są możliwości składania względem siebie obciążających zeznań ${ }^{23}$.

Interpretację takich konsekwencji relacji patronów i wyzwoleńców pozostaje skonfrontować z przytaczanymi na początku artykułu przekazami Paulusa i Ulpianusa na temat trwałych i bezwzględnych dyskwalifikacji tych podmiotów od wzajemnego zeznawania na niekorzyść na gruncie lex Iulia de vi. Pozorną sprzeczność między fragmentami wydaje się bez trudu wythumaczyć wzajemną relacją ustaw - lex Iulia iudiciorum publicorum miała zastosowanie, gdy wchodząca w grę lex specialis (jak na przykład lex Iulia de vi) nie stanowiła inaczej24. We wskazanym przypadku swoistym minimum zapewnionym przez lex generalis było uprawnienie do odmowy złożenia zeznań na niekorzyść ${ }^{25}$, ustawa szczególna zaś mogła i w zakresie przestępstwa vis przewidziała bezwzględną i trwałą dyskwalifikację świadków występujących wobec siebie w relacji patron-wyzwoleniec $\mathrm{w}$ odniesieniu do zeznań niekorzystnych ${ }^{26}$. Jednocześnie wydaje się możliwe, także na gruncie lex Iulia de vi, dopuszczenie wzajemnych zeznań patronów i wyzwoleńców na korzyść. Późniejsze regulacje wprowadziły natomiast generalny zakaz składania zeznań obciążających przeciw swym patronom oraz wyzwoleńcom.

Pozostaje zatem kwestia małżeństwa jako, jak się wydaje, dość oczywistej podstawy co najmniej prawa do odmowy zeznań. W źródłach odnoszących się zarówno do julijskiej lex generalis, jak i lex Iulia de vi brakuje jakichkolwiek wzmianek na temat uprawnień żony czy męża, co sugerowałoby, że relacja ta nie rodziła żadnych dyskwalifikacji czy uprawnień do uchylenia się od zeznań niekorzystnych dla współmałżonka. Przy zapewnieniu jednak takiego prawa nawet kuzynom oskarżonego sytuacja wydaje się kuriozalna. Pierwszym tekstem, który — pod pewnymi warunkami — daje możliwości interpretacji uwzględniającej małżonków jako uprawnionych do odmowy zeznań niekorzystnych, jest poniższy fragment Pauli Sententiae 5.15.2:

Pauli Sententiae: „In adfinem vel cognatum inviti testes interrogari non possunt".

W związku z ogólnym określeniem kategorii osób, których nie można przesłuchiwać na niekorzyść oskarżonego wbrew ich woli, jako powinowatych lub

23 Podkreślenia wymaga, że konstytucja cesarzy Honoriusa i Theodosiusa z roku 423 (C. 4.20.12= B. 21.1.36; C.Th. 9.6.4) powinna być odnoszona jedynie do oskarżeń formułowanych przez wyzwoleńców, nie zaś do ich zeznań. Tak też W. Rozwadowski, Wartość dowodowa świadków..., s. 5-6.

24 Zob. też A.D. Manfredini, op. cit., s. 232, 241.

25 O generalnym charakterze zwolnienia od obowiązku zeznawania w tym zakresie, być może odpowiadającym wcześniej już funkcjonującym zwyczajowym uprawnieniom tych podmiotów, U. Vincenti, op. cit., s. 72. Dalsze rozszerzenia poświadczone są w D. 22.5 .5 oraz 8; ibidem, s. 73. Por. też A.W. Zumpt, op. cit., s. 270.

${ }^{26} \mathrm{Na}$ temat ograniczenia zasad wprowadzonych przez lex Iulia de vi jedynie do spraw o przestępstwo vis, bez możliwości przyjęcia ich ogólniejszego charakteru, por. A. Nogrady, op. cit., s. 233. 
kognatów ${ }^{27}$, istniałaby możliwość uznania uprawnień do odmowy zeznań małżonka, gdyby uznać go za mieszczącego się w grupie osób, z którymi oskarżonego łączą więzy oparte o adfinitas. Założenie takiego rozumienia powinowactwa wykluczone jest jednak przez wyraźne wskazanie przez Modestinusa relacji powinowactwa jako łączącego jednego małżonka z rodziną (kognatami) drugiego 28 .

D. 38.10.4.3:

Sed quoniam quaedam iura inter adfines quoque versantur, non alienum est hoc loco de adfinibus quoque breviter disserere. Adfines sunt viri et uxoris cognati, dicti ab eo, quod duae cognationes, quae diversae inter se sunt, per nuptias copulantur et altera ad alterius cognationis finem accedit: namque coniugendae adfinitatis causa fit ex nuptiis.

Dodatkowo jurysta wyraźnie wymienia osoby uznawane za powinowatych, a wśród nich teścia, teściową (świekra, świekrę), zięcia, synową, ojczyma, macochę, pasierba i pasierbicę.

D. 38.10.4.4: „Nomina vero eorum haec sunt: socer socrus, gener nurus, noverca vitricus, privignus privigna".

$\mathrm{Na}$ podstawie wskazanych tekstów nie ma wątpliwości, że relacja między małżonkami nie może być zaliczona do opartych na powinowactwie. Jednak taki pogląd w literaturze występuje ${ }^{29}$ i, jak się wydaje, wywodzi się z przytoczonego w paragrafie 302 Fragmenta Vaticana stanowiska Paulusa (libro LXXI ad edictum, ad Cinciam), zgodnie z którym pośród powinowatych, co do których znajduje zastosowanie definicja i wyraźne wskazanie Modestinusa (pasierb, pasierbica, macocha, ojczym, teść, teściowa, zięć, synowa), wymienieni są też małżonkowie oraz narzeczeni ${ }^{30}$ :

Excipiuntur et adfinium personae ut privignus privigna, noverca uitricus, socer socrus, gener nurus, vir et uxor, sponsus sponsa.

Rozszerzenie pojęcia osób spowinowaconych dokonane przez jurystę nie wydaje się mieć charakteru generalnego, dotycząc jedynie wyłączeń od ograniczeń wprowadzonych lex Cincia, której to ustawy dotyczyła jego wypowiedź. Interpretacja ta nie może rzutować na pojęcie adfinitas jako takie, odnosząc się także do relacji narzeczeńskich ${ }^{31}$. Jakkolwiek bardzo często uprawnienia związane z po-

27 O prawie odmowy zeznań na gruncie tego fragmentu zob. np. G. Pugliese, op. cit., s. 233-234.

28 Taką definicję powinowactwa przyjmuje też np. A. Berger, Encyclopedic Dictionary of Roman Law, Philadelphia 1953, s. 349, s.v. adfinitas; G. Branca, s.v. affinità, [w:] Enciclopedia del diritto, t. 1, red. F. Calasso, Milano 1958, s. 690. Por. też F. Baudry, Affinitas, [w:] Dictionnaire des Antiquités Grecques et Romaines, t. 1, red. C. Daremberg, E. Saglio, Paris 1877, s. 128; R. Leonhard, s.v. adfinitas, [w:] Paulys Realencyclopädie der classischen Altertumswissenschaft, t. 1, red. G. Wissowa, Stuttgart 1894, col. 358.

${ }^{29}$ Zob. np. G. Long, s.v. affinitas, [w:] A Dictionary of Greek and Roman Antiquities, red. W. Smith, London 1875, s. 28; R. Astolfi, Il matrimonio nel diritto romano classico, Padova 2006, s. 142.

30 Por. analizę fragmentu u A. Guarino, Adfinitas, Milano 1939, s. 43-46.

$31 \mathrm{Na}$ temat adfinitas w odniesieniu do relacji narzeczeńskich, zob. ibidem, s. 13-28. 
zostawaniem w małżeństwie, a odnoszące się bezpośrednio do sytuacji związanej z małżonkiem, rozszerzane były per analogiam na stosunki narzeczeńskie, zawsze juryści odnosili się do tego zabiegu wprost. Nie jest możliwe generalne uznanie, że więzy powinowactwa, które zgodnie z przekazem Modestinusa rodzą się $\mathrm{z}$ zawarcia małżeństwa, istnieją także w sytuacji poprzedzającej jego zaistnienie (a zatem w jego braku). Należy zatem przyjąć, że wskazany przekaz Paulusa odnosić można jedynie do szczególnej regulacji, której dotyczyła jego wypowiedź. Dodatkowo najważniejsze konsekwencje relacji opartej na powinowactwie, w postaci zakazu zawierania małżeństw osób spowinowaconych ${ }^{32}$, nie mają racji bytu przy przyjęciu, że adfinitas rozciąga się na małżonków i narzeczonych.

Dla analizowanej w niniejszym artykule kwestii prawa do odmowy zeznań uznanie, że małżonkowie nie mogą być zakwalifikowani do grona powinowatych, ma kluczowe znaczenie, jako że eliminuje ich z kręgu osób uprawnionych do uchylenia się od wzajemnego składania zeznań na niekorzyść. Tym samym nawet fragment Pauli Sententiae nie może być wykorzystany jako uprawdopodabniający istnienie takiego uprawnienia.

Z powyższych rozważań wyłania się zatem obraz rzymskiego postępowania karnego $\mathrm{z}$ jednej strony ukierunkowanego na pozyskanie wiarygodnych zeznań, $\mathrm{z}$ drugiej - szanującego bliskie relacje wynikające $\mathrm{z}$ pokrewieństwa, powinowactwa czy wyzwolenia. Dla okresu klasycznego zasadnie można przyjąć, że nie istniał jeden reżim dyskwalifikacji od zeznawania czy system uprawnień do odmowy zeznań. Jakkolwiek za podstawową regulację w tym zakresie z pewnością można uznać lex Iulia iudiciorum publicorum — prawdopodobnie miała ona zastosowanie, jedynie gdy ustawa szczególna, wprowadzająca zasady postępowania przed daną quaestio nie stanowiła inaczej. Dodatkowo wobec braku zachowania tekstu ustawy dysponujemy jedynie fragmentem odnoszącym się do prawa odmowy zeznań na jej gruncie, bez jakichkolwiek bezpośrednich odniesień do wyłączeń od występowania w roli świadka na niekorzyść oskarżonego. $\mathrm{Z}$ tego względu ogólne stwierdzenia o dyskwalifikacji świadków w tym zakresie, formułowane przez jurystów późniejszych, mogą, lecz nie muszą być odnoszone do reżimu wprowadzonego julijską ustawą „ogólną”. Z regulacji ustaw szczególnych

32 Zob. Gai Institutiones 1.63: „Item amitam et materteram uxorem ducere non licet. Item eam, quae mihi quondam socrus aut nurus aut privigna aut noverca fuit. Ideo autem diximus 'quondam', qula, si adhuc constant eae nuptiae, per quas talis adfinitas quaesita est, alia ratione mihi nupta esse non potest, quia neque eadem duobus nupta esse potest neque idem duas uxores habere". Późniejsze rozszerzenie zakazu zawierania małżeństw między powinowatymi poświadczone jest z kolei w C. Th. 3.12.2 („Etsi licitum veteres crediderunt, nuptiis fratris solutis ducere fratris uxorem, licitum etiam, post mortem mulieris aut divortium contrahere cum eiusdem sorore coniugium, abstineant huiusmodi nuptiis universi, nec aestiment, posse legitimos liberos ex hoc consortio procreari: nam spurios esse convenit, qui nascentur"). Zob. G. Schiemann, Adfinitas, [w:] Der Neue Pauly, red. H. Cancik, H. Schneider, http://dx.doi.org/10.1163/1574-9347_dnp_e103490 (dostęp: 19 listopada 2018). 
w zakresie tych zagadnień znane są jedynie odniesienia do lex Iulia de vi, która zawierała szeroki katalog dyskwalifikacji, a także wzmianki o prawie odmowy zeznań. Fragmentaryczność i niewielka liczba źródeł nie pozwala więc na wyciągnięcie pewnych wniosków co do klasycznych uregulowań prawa do uchylenia się od zeznań na niekorzyść oskarżonego. Największe wątpliwości budzą w tym zakresie relacje rodzice-dzieci, patroni-wyzwoleńcy oraz zupełnie w źródłach pominięta kwestia uprawnień współmałżonka. Należy jednak uznać, że w okresie klasycznym nie istniały powszechne zakazy składania wzajemnych zeznań obciążających w tych przypadkach, lecz jedynie prawo odmowy zeznań. Odrębności w postępowaniach przed quaestio de vi dyskwalifikujące wyzwoleńców od wystąpienia z zeznaniem na niekorzyść patronów lub wskazanych osób z nimi związanych należy uznać za partykularyzmy wprowadzone tylko w odniesieniu do tego przestępstwa. Dopiero okres poklasyczny przyniósł zakazy występowania z niekorzystnym zeznaniem świadków będących rodzicami, dziećmi, patronami czy wyzwoleńcami oskarżonego. Na szczególną uwagę zasługuje w tym kontekście wyjaśnienie tej zasady prezentowane w Pauli Sententiae — chodziło bowiem o uznanie relacji tego rodzaju za tak bliskie, że zazwyczaj zniekształcały, wypaczały dowód ze złożonych zeznań, czyniąc go bezużytecznym. Przesłanką dyskwalifikacji zeznań tych podmiotów było więc aprioryczne założenie braku wiarygodności świadków. Zasadnicza różnica między wspomnianymi kategoriami polegała jednak na tym, że w relacjach rodzice-dzieci oraz patroni-wyzwoleńcy chodziło jedynie o zeznania na niekorzyść. Prawo odmowy obciążających zeznań pozostałych kognatów oraz powinowatych, a także — prawdopodobnie — osób niezawdzięczających bezpośrednio swej wolności oskarżonym, lecz ją pośrednio wywodzących od nich lub ich bliskich, obecne w prawie klasycznym, przetrwało także w okresie poklasycznym.

\section{Bibliografia}

Astolfi R., Il matrimonio nel diritto romano classico, Padova 2006.

Baudry F., Affinitas, [w:] Dictionnaire des Antiquités Grecques et Romaines, red. C. Daremberg, E. Saglio, t. 1, Paris 1877.

Bauman R.A., The 'leges iudiciorum publicorum' and Their Interpretation in the Republic, Principate and Later Empire, [w:] Aufstieg und Niedergang der römischen Welt, t. 2.13, Berlin 1980.

Berger A., Encyclopedic Dictionary of Roman Law, Philadelphia 1953.

Branca G., s.v. affinità, [w:] Enciclopedia del diritto, t. 1, red. F. Calasso, Milano 1958.

Casavola F.P., Gli ordinamenti giudiziari nella Roma imperiale. »Princeps « e procedure dalle leggi Giulie ad Adriano, „Index” 26, 1998.

Cohen B., Testimonial Compulsion in Jewish, Roman, and Moslem Law, „IVRA” 9/1, 1958.

Fanizza L., Giuristi, crimini, leggi nell'età degli Antonini, Napoli 1982.

Gatti T., I limiti delle leges iudiciorum publicorum, „Archivio Giuridico” 113, 1935.

Gatti T., I limiti delle leges iudiciorum publicorum, „Archivio Giuridico” 115, 1936. 
Giltaij J., The problem of the content of the Lex Iulia iudiciorum publicorum, „Tijdschrift voor Rechtsgeschiedenis" 81, 2013.

Giuffre V., La repressione criminale nell'esperienza romana, Napoli 1997.

Guarino A., Adfinitas, Milano 1939.

Kunkel W., Quaestio, [w:] Kleine Schriften, Weimar 1974.

Leonhard R., s.v. adfinitas, [w:] Paulys Realencyclopädie der classischen Altertumswissenschaft, t. 1, red. G. Wissowa, Stuttgart 1894.

Long G., s.v. affinitas, [w:] A Dictionary of Greek and Roman Antiquities, red. W. Smith, London 1875.

Manfredini A.D., La testimonianza del liberto contro il patrono nel processo criminale di età classica, [w:] Studi in onore di Arnaldo Biscardi, t. 3, Milano 1982.

Messina S., La testimonianza nel processo penale romano, „Rivista penale” 73, 1911.

Nogrady A., Römisches Strafrecht nach Ulpian: Buch 7 bis 9 De officio proconsulis, Berlin 2006.

Piacente D.V., Casi di incapacità a testimoniare tra legislazione e giurisprudenza, „Index” 42, 2014.

Pugliese G., La prova nel processo romano classico, „Jus” 11, 1960.

Rozwadowski W., Ocena zeznań świadków w procesie rzymskim epoki Pryncypatu, „Czasopismo Prawno-Historyczne" 16, 1964.

Rozwadowski W., Ocena zeznań świadków w procesie rzymskim epoki republikańskiej, „Czasopismo Prawno-Historyczne" 13, 1961.

Rozwadowski W., Wartość dowodowa świadków w rzymskim procesie poklasycznym, „Czasopismo Prawno-Historyczne" 21, 1969.

Schiemann G., Adfinitas, [w:] Der Neue Pauly, red. H. Cancik, H. Schneider, http://dx.doi.org/ 10.1163/1574-9347_dnp_e103490.

Simon D., Untersuchungen zum justinianischen Zivilprozess, München 1969.

Vincenti U., »Duo genera sunt testium«. Contributo allo studio dela prova testimoniale nel processo romano, Padova 1989.

Zumpt A.W., Das Criminalrecht der Römischen Republik, Berlin 1869.

\section{Exemption from testifying and the right to refuse to testify in Roman criminal procedure}

Summary

The author of article examines the scope of the exemption from testifying for the prosecution and the right to refuse to testify in the Roman criminal procedure before quaestiones. She focuses mainly of Callistratus' and Ulpian's accounts of lex Iulia de vi and Paulus' account of lex Iulia iudiciorum publicorum. This is because there are doubts, especially with regard to the nature of rights or exemptions applying to testimonies concerning relations based on close kinship (parents-children) or patronage as well as marriage.

Keywords: testimony of witnesses, right to refuse to testify, taking of evidence in criminal cases, testimonium, testes excepti, testes interdicti 


\section{Das Recht der Aussageverweigerung oder die Freistellung von Aussagen im römischen Strafprozess}

Zusammenfassung

In diesem Aufsatz wurde der Umfang der Gültigkeit der Disqualifikation als Zeuge der Anklage aufzutreten sowie das Recht der Aussageverweigerung im römischen Strafprozess vor den quaestiones behandelt. Die Analyse konzentriert sich hauptsächlich auf Überlieferungen von Callistratus und Ulpianus betreffend die Regelungen von lex Iulia de vi sowie von Paulus betreffend lex Iulia iudiciorum publicorum. Vor diesem Hintergrund entstehen nämlich Zweifel besonders hinsichtlich des Charakters der Berechtigungen oder der Freistellungen im Bereich der gegenseitigen Aussagen im Zusammenhang mit der Relation, die auf naher Verwandtschaft (Eltern - Kinder) oder dem Patronat, wie auch der Ehe beruhte.

Schlüsselworte: Zeugenaussagen, das Recht auf Verweigerung der Aussage, Beweisaufnahme in Strafsachen, testimonium, testes excepti, testes interdicti 